\title{
Strength benefit of sawdust/wood ash amendment in cement stabilization of an expansive soil
}

Fecha de recepción: 2 de noviembre de 2018

Jijo James ${ }^{1}$

Fecha de aprobación: 18 de diciembre de 2018

\begin{abstract}
The investigation evaluated the strength benefits obtained by amending cement stabilization of an expansive soil by using saw dust ash (SDA), a waste generated in wood milling industries due to burning. The experimental program involved the preparation of cylindrical specimens of size $38 \mathrm{~mm} \times 76 \mathrm{~mm}$ for evaluating the unconfined compression strength (UCS) of the cement stabilized and amended samples cured for varying periods of 2 hours, 7,14 and 28 days. Two cement contents of $2 \%$ and $6 \%$ by weight of soil were adopted to stabilize the soil. The SDA amended cement stabilized samples adopted SDA contents of $5 \%, 10 \%$ and $20 \%$ by weight of soil. Strength gain trends for the amended samples were also fitted based on the results of the UCS tests. In order to analyse benefits in pavement design and thickness reduction, the UCS values were used to predict the CBR value of the specimens based on which the reduction in pavement thickness was calculated for different traffic densities. The investigation revealed that $5 \%$ SDA amendment of cement stabilization can result in up to $26 \%$ increase in early strength and $20 \%$ increase in delayed strength. Based on the predicted CBR values, pavement thickness can be reduced up to $8.3 \%$.
\end{abstract}

Keywords: ash; roads; soil; strength; waste management; waste material.

\section{Beneficio de la resistencia de la enmienda al aserrín/ceniza de madera en la estabilización de cemento de un suelo expansivo}

\section{Resumen}

La investigación evaluó los beneficios de resistencia obtenidos al modificar la estabilización del cemento de un suelo expansivo mediante el uso de cenizas de polvo de sierra (SDA), un residuo generado en las industrias de molienda de madera debido a la quema. El programa experimental consistió en la preparación de muestras cilíndricas de tamaño $38 \mathrm{~mm}$ x $76 \mathrm{~mm}$ para evaluar la resistencia a la compresión no confinada (UCS) del cemento estabilizado y las muestras modificadas curadas por períodos variables de 2 horas, 7, 14 y 28 días. Se adoptaron dos contenidos de cemento de $2 \%$ y $6 \%$ en peso de suelo para estabilizar el suelo. Las muestras estabilizadas de cemento modificadas por SDA adoptaron contenidos de SDA del 5\%, 10\% y $20 \%$ en peso del suelo. Las tendencias de aumento de la fuerza para las muestras modificadas también se ajustaron en función de los resultados de las pruebas de UCS. Con el fin de analizar los beneficios en el diseño del pavimento y la reducción del espesor, los valores de UCS se usaron para predecir el valor CBR de los especímenes en base a los cuales se calculó la reducción del espesor del pavimento para diferentes densidades de tráfico. La investigación reveló que la enmienda 5\% SDA de la estabilización del cemento puede dar como resultado un aumento de hasta el $26 \%$ en la resistencia temprana y un aumento del $20 \%$ en la resistencia

${ }^{1}$ Ph. D. SSN College of Engineering (Tamil Nadu, India). iijoj@ssn.edu.in. ORCID: 0000-0002-1167-8066.

Revista Facultad de Ingeniería (Rev. Fac. Ing.) Vol. 28 (50), pp. 44-61. Enero-Marzo, 2019. Tunja-Boyacá, Colombia. L-ISSN: 0121-1129, e-ISSN: 2357-5328, DOI:

https://doi.org/10.19053/01211129.v28.n50.2019.8790 
retardada. Según los valores de CBR previstos, el grosor del pavimento se puede reducir hasta el $8.3 \%$.

Palabras clave: caminos; ceniza; material de desecho; resistencia; suelo.

\section{Benefício da resistência da emenda ao serragem/cinzas de madeira na estabilização de cimento de um solo expansivo}

\section{Resumo}

A pesquisa avaliou os benefícios de resistência obtidos ao modificar a estabilização do cimento de um solo expansivo mediante o uso de cinzas de pó de serra (SDA), um resíduo gerado nas indústrias de moagem de madeira devido à queima. O programa experimental consistiu na preparação de amostras cilíndricas de tamanho $38 \mathrm{~mm} \times 76 \mathrm{~mm}$ para avaliar a resistência à compressão não confinada (UCS) do cimento estabilizado e as amostras modificadas curadas por períodos variáveis de 2 horas, 7, 14 e 28 dias. Adotaram-se dois conteúdos de cimento de $2 \%$ e $6 \%$ em peso de solo para estabilizar o solo. As amostras estabilizadas de cimento modificadas por SDA adotaram conteúdos de SDA de $5 \%, 10 \%$ e $20 \%$ em peso do solo. As tendências de aumento da força para as amostras modificadas também se ajustaram em função dos resultados das provas de UCS. Com o fim de analisar os benefícios no desenho do pavimento e a redução da espessura, os valores de UCS foram usados para predizer o valor CBR dos espécimes em base aos quais se calculou a redução da espessura do pavimento para diferentes densidades de tráfego. A pesquisa revelou que a emenda 5\% SDA da estabilização do cimento pode dar como resultado um aumento de até $26 \%$ na resistência inicial e um aumento de $20 \%$ na resistência tardia. Segundo os valores de CBR previstos, a grossura do pavimento pode ser reduzida até $8.3 \%$.

Palavras chave: caminhos; cinzas; material residual; resistência; solo.

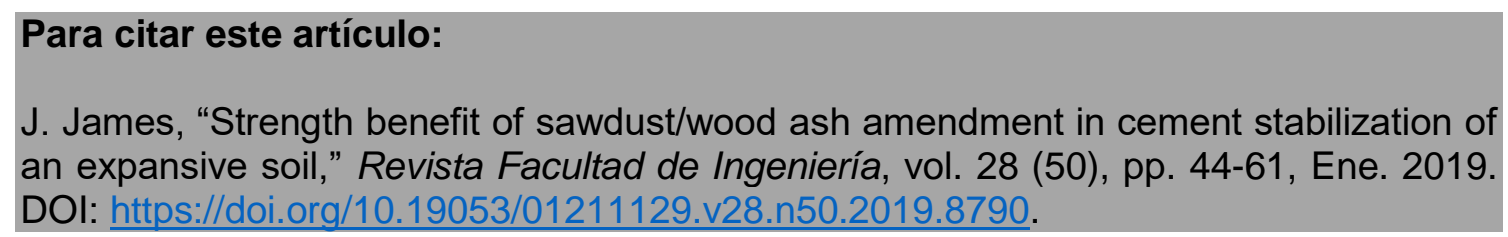

Esta obra está bajo licencia internacional Creative Commons Reconocimiento 4.0

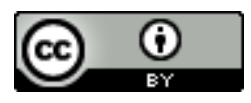




\section{Introduction}

Poor soils have been encountered by geotechnical engineers all over the world during developmental activities and execution of infrastructure projects. They have always posed a problem for the engineers in one way or the other, either during or after construction. Such poor soils can exhibit several undesirable characteristics like low strength and bearing, excessive swelling, highly compressible nature and resultant settlement to name a few. In order to make the soil a suitable engineering material, its properties need to be modified or engineered to suit the requirements of a particular infrastructure project. This can be achieved by stabilizing the soil by any of the several means available. One such method is chemically stabilizing the soil by addition of binders like cement and lime. Cement and lime have been by far the most common additives adopted for stabilizing such poor soils with undesirable properties. In recent times, addition of solid wastes has also been practiced to improve soils of various types to suit varying requirements [1], [2]. Solid wastes can originate from industrial, domestic, agricultural or mineral sources. Biomass ashes originating from agricultural / horticultural sources have found an increased acceptance in their utilization in Civil Engineering materials like concrete and soil modification.

One such biomass waste ash is sawdust ash (SDA). Sawdust or technically wood dust is a by-product waste in the form of fine granules of wood that is generated during wood working operations like sawing, milling, planing, drilling and sanding of timber in timber industries that process timber to be supplied for various allied manufacturing industries. This sawdust is predominantly used in particle boards, though they do have other applications like making wood pulp, mulch, charcoal briquettes and as fuel. In sawmills, where they are generated in huge quantities, they are also used in the sawdust burners to produce heat for milling operations. The resultant end product is SDA or wood ash (WA). SDA has found applications in manufacture of concrete and more recently, in soil stabilization and stabilized soil blocks.

Several researchers have worked on the utilization of SDA as a standalone stabilizer as well as in combinations with primary binders like cement and lime. Different investigators have worked on the various geotechnical properties of soils [3-11], burnt clay bricks [12] and highway subgrade [13-14] stabilized using SDA. However, Butt et al. [4] and Raheem et al. [15] indicate SDA to be a pozzolanic material due to its high siliceous content. A pozzolan is a material of finely divided siliceous or aluminous composition which forms cemented products in the presence of water and calcium hydroxide [16]. Thus, it would seem prudent to use SDA along with a primary binder rather than as a standalone stabilizer.

There are records in literature wherein industrial solid wastes in combination with primary binders have given much better results than them being used as standalone stabilizers and can also result in pozzolanic strength gain over primary binder stabilization alone [17]. Some researchers have adopted combinations of SDA and primary stabilizers like lime and cement in soil stabilization, stabilized blocks and highway construction [18-23]. It can be seen that researchers have adopted SDA in stabilizing the soil, predominantly as a standalone stabilizer. Investigations dealing with its use in combination with lime and cement are limited. Thus, this work aims at the evaluating the potential of 
SDA used in combination with cement and analysing the strength benefit achieved, when used for highway subgrades.

\section{Materials and methods}

The various materials adopted in this investigation include an expansive soil which was stabilized and the stabilizer combination of SDA and Cement. The expansive soil used in the investigation was collected from Thiruvallur district of Tamil Nadu, India. The soil was characterized in the laboratory and classified in accordance with the codes of Bureau of Indian Standards (BIS). The properties of the soil determined in the laboratory is tabulated in Table 1. The cement adopted for this investigation was commercially available ordinary Portland cement (OPC). The SDA adopted in the investigation was collected as saw dust from a local saw mill, was burnt in an open pan and sieved through BIS 600 Micron sieve before its use in the investigation.

Table 1. Geotechnical properties of the soil.

\begin{tabular}{|l|c|}
\hline \multicolumn{1}{|c|}{ Property } & Value \\
\hline Liquid Limit (\%) [24] & 63.3 \\
\hline Plastic Limit (\%) [24] & 25.8 \\
\hline Plasticity Index (\%) & 37.5 \\
\hline Shrinkage Limit (\%) [25] & 11.2 \\
\hline Specific Gravity [26] & 2.67 \\
\hline Maximum Dry Density (kN/m ${ }^{3}$ ) [27] & 15.4 \\
\hline Optimum Moisture Content [27] & 25.1 \\
\hline Unconfined Compression Strength (UCS) (kPa) [28] & 249.6 \\
\hline Free Swell Index (\%) [29] & 98.0 \\
\hline Soil Classification [30] & $\mathrm{CH}$ \\
\hline
\end{tabular}

The methodology of the investigation involved the following stages of investigation: characterization of soil, selection of stabilizer content, preparation and curing of test specimens and testing. The soil sample was characterized in the geotechnical laboratory for its properties in accordance with the various codes of BIS followed by classification. This was followed by selection of the cement content required for stabilization of the soil. Cement stabilized soils are usually classified into soil cement, cement bound material and lean concrete/soil concrete [31]. Soil cement usually contains less than $5 \%$ cement. Based on this, two cement contents one below and the other above $5 \%$ was adopted in this investigation. Similar choice of cement content was also adopted in an earlier investigation [32]. Three SDA contents were selected at random for use along with the cement for stabilization. Weighed oven dried soil sample was mixed manually by hand with cement and SDA by weight of soil, in dry state and then water was sprinkled in stages to get a uniform wet mix.

This wet mix was then packed into a split mould to prepare test specimens of dimensions $38 \mathrm{~mm} \times 76 \mathrm{~mm}$ by static compaction, prepared to the maximum dry density and optimum moisture content. The samples were then packed in polythene covers and sealed to prevent loss of moisture and maintained at a temperature of $30^{\circ} \mathrm{C}+/-2^{\circ} \mathrm{C}$ for curing over periods of 2 hours, 7,14 and 28 days. After the designated curing periods, the specimens were removed from the polythene covers and tested within a period of half an hour by straining them axially at a rate of $0.625 \mathrm{~mm} / \mathrm{minute}$ until the failure of the samples. Three 
specimens were prepared for each combination and the average strength of the three was recorded.

\section{Results and discussion}

The expansive soil was stabilized using $2 \%$ and $6 \%$ cement. Three trial contents of SDA adopted in the investigation, selected at random were 5\%, $10 \%$ and $20 \%$. The effect of SDA addition on the strength of the stabilized soil is described in the following sections.

\section{A. Uniaxial strength of SDA amended cement stabilized soil}

Figure 1 shows the strength of $2 \%$ cement stabilized soil amended with SDA. The first obvious inference is the gain in strength due to the addition of SDA to cement stabilization of soil. The development of strength begins right after the amendment of cement stabilization with SDA. Even at two hours of curing there is a slight increase in strength of the stabilized soil when 5\% SDA is added to the cement stabilized soil. The strength of the stabilized soil increased from 324.63 $\mathrm{kPa}$ to $359.36 \mathrm{kPa}$. Further increase in SDA did not result in any higher strength gain.

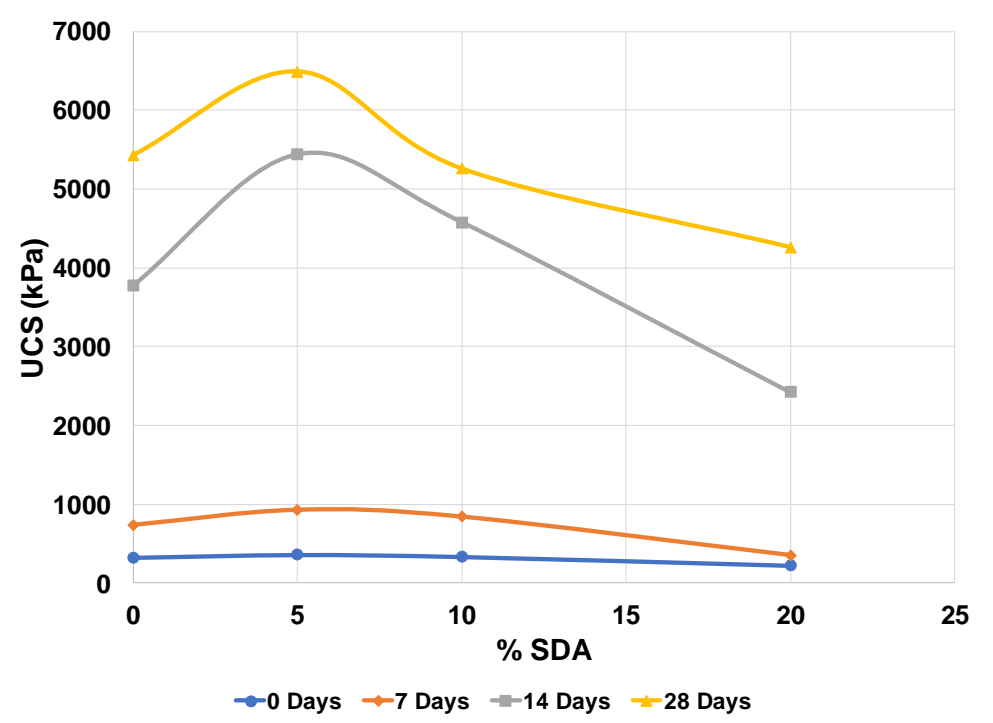

Fig. 1. UCS of $2 \%$ cement stabilized soil amended with SDA.

At 7 days of curing, there is a clear hump in the curve, indicating a prominent gain in strength for $5 \%$ and $10 \%$ addition of SDA to $2 \%$ cement stabilization. However, the strength gain of $5 \%$ SDA was better than the strength gains of $10 \%$ SDA. Addition of $20 \%$ SDA, however, resulted in a loss in strength compared to $2 \%$ cement stabilized soil. At 14 days of curing, the trends are similar with $5 \%$ SDA gaining the maximum strength and $20 \%$ SDA resulting in a strength loss. At 28 days of curing, the gain in strength was significant for 5\% SDA with the strength jumping from $5423.25 \mathrm{kPa}$ to $6489.23 \mathrm{kPa}$. However, 10\% SDA, which had strength gain until 14 days of curing, could not sustain the gain and marginally lost strength resulting in a strength of $5256.39 \mathrm{kPa}$. Kharun and Svintsov [33] have reported strengths in the range of $4 \mathrm{MPa}$ to $10 \mathrm{MPa}$ for cement contents varying from close to $6 \%$ to $15 \%$ in soil concrete at 28 days of air-humid curing. James and Pandian [34] have reported strengths of cement stabilized soil in the range of 2 to $2.5 \mathrm{MPa}$ for cement contents between $1 \%$ and $4 \%$ at 7 days of air 
curing. Saride et al. [35] reported strengths of cement treated organic soils in the range of $1.5 \mathrm{MPa}$ to $3.5 \mathrm{MPa}$ at 28 days of curing. Figure 2 shows the influence of SDA addition on $6 \%$ cement stabilized soil.

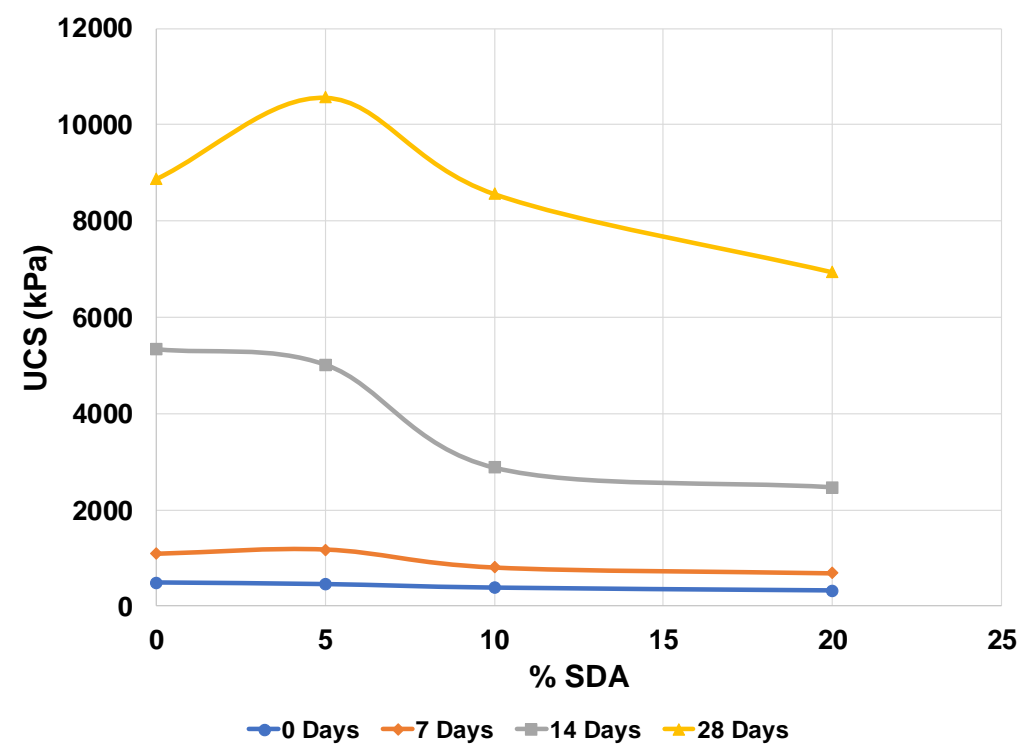

Fig. 2. UCS of $6 \%$ cement stabilized soil amended with SDA.

In the case of $6 \%$ cement stabilized soil as well, it can be seen that the strength development trends are the same with one major difference. In the case of $2 \%$ cement stabilization, early strength development trends indicated positive strength gain for both $5 \%$ and $10 \%$ SDA whereas in the case of $6 \%$ cement stabilization, it is not so, with $10 \%$ SDA amendment resulting in a strength loss right from immediate and early curing. In fact, at the higher cement content, even $5 \%$ SDA could not produce positive immediate strength at a curing of 2 hours wherein the strength dropped from $487.23 \mathrm{kPa}$ to $454.36 \mathrm{kPa}$. However, $5 \%$ SDA amendment gains sufficient strength over extended curing periods to overtake the strength gained by pure cement stabilized soil. At 28 days of curing, the strength of $5 \%$ SDA amended cement stabilized soil develops a strength of $10567.5 \mathrm{kPa}$ against the strength of $8880.25 \mathrm{kPa}$ of pure $6 \%$ cement stabilized soil. Basha et al. [36] reported an increase in strength of $4 \%$ cement stabilized residual soil from $0.99 \mathrm{MPa}$ to $3.7 \mathrm{MPa}$ for $15 \%$ addition of rice husk ash. The general trend seen for SDA amendment of cement stabilization of soil is that there is a reduction in strength with increase in SDA content. Similar trends have been reported by other investigators as well [15, 21-22].

For a better understanding of the relationship between the stabilizers SDA and cement and the strength development patterns, for different cement contents, an attempt was made to arrive at an equation relating the binder content and the strength developed. Similar attempt was also made by Kharun and Svintsov [33] for soil concrete for prediction of strength of the stabilized soil. Since, two different stabilizers were used for the soil, the stabilizer content was reduced to a ratio of SDA to cement named as pozzolan/binder ratio (PBR). In order to ensure that the benefit of SDA addition to cement be represented, the strength was reduced as a ratio between control sample to amended sample, called as strength gain ratio (SGR). Figure 3 shows the trendlines for $2 \%$ and $6 \%$ cement stabilized soil amended with SDA. 


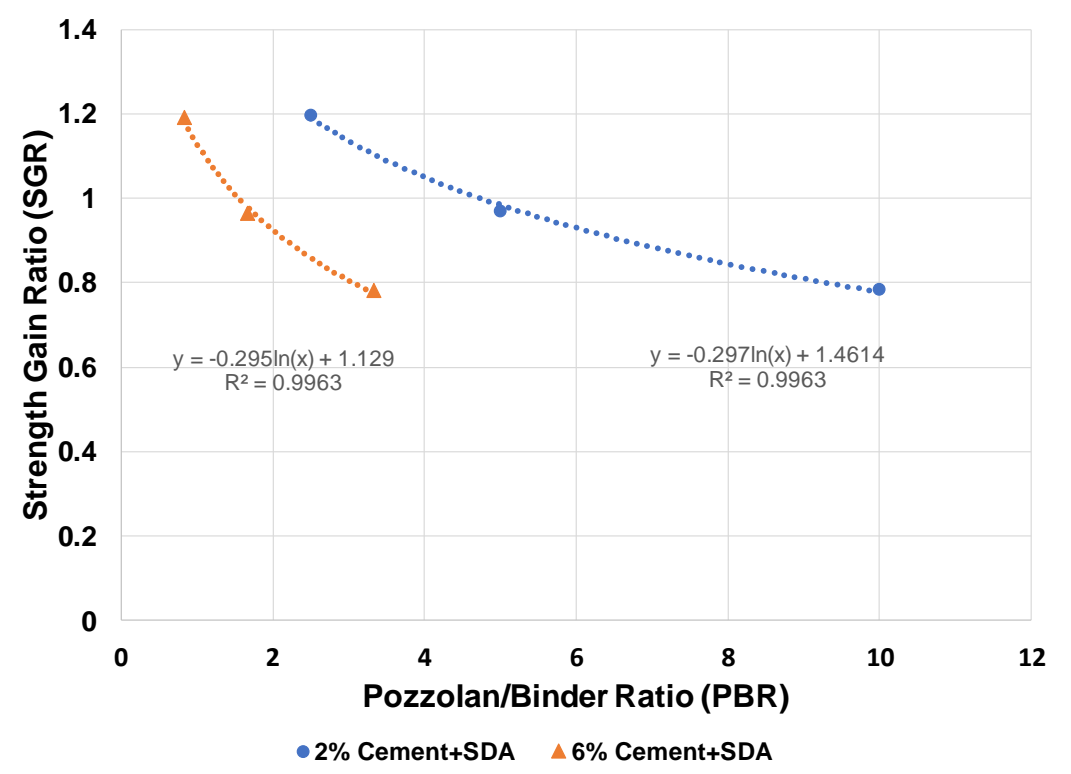

Fig. 3. Trendlines for $2 \%$ and $6 \%$ cement stabilization amended with SDA.

It can be clearly seen that the trends of the relationship between PBR and SGR for both cement contents is similar. The coefficients and constants of the curve fit for both the cases are close to each other indicating similarity in the trends. The coefficient of determination $\left(R^{2}\right)$ for both the curves is very good at 0.9963 indicating a good fit and minimal variation. However, it should be remembered that the trendlines fitted are only applicable for SDA amended cement stabilization. Based on the equations adopted for both the cement contents, it was found that for the SGR to be at least 1 , that is no loss in strength, the PBR should be 4.73 for a cement content of $2 \%$ and 1.55 for a cement content of $6 \%$. Based on these boundary values, it was found that the maximum SDA content for no strength loss was found to be $9.46 \%$ and $9.29 \%$ respectively for $2 \%$ and $6 \%$ cement stabilization.

Thus, it can be stated that for effective utilization of SDA without strength loss, the maximum SDA content should be limited to $9 \%$ for cement stabilization wherein the cement content is $5 \%$ and below (soil-cement). This is in agreement with the analysis done by Chowdhury et al. [37] who state that up to $10 \%$ WA by weight can be used in place of cement for structural concrete. Similarly, Shawl et al. [20] also reported an increase in strength of lime stabilized lateritic soil for up to $8 \%$ SDA beyond which there was a decrease in strength, when SDA was raised to 12\%. Tygher et al. [21] also reported that SDA content should be restricted to a maximum of $10 \%$ for lime stabilized sandcrete blocks. In order to check the validity of the statement, an attempt was made to predict the relationship between PBR and SGR for a cement content of $4 \%$ and SDA contents of $5 \%, 10 \%$ and $20 \%$, keeping the relationships arrived for $2 \%$ and $6 \%$ cement contents as lower and upper boundaries. For checking the validity of the model, only 28 -day cured samples of $4 \%$ cement stabilized specimens amended with $5 \%, 10 \%$ and $20 \%$ SDA were cast and tested.

Figure 4 shows the forecasted model for $4 \%$ cement stabilized soil amended with SDA. Based on the forecast, the trendline for $4 \%$ cement stabilized soil amended 
with SDA has been plotted in relation to the boundary value trendlines. From the predicted model for SDA amended $4 \%$ cement stabilized soil, the maximum SDA content for no strength loss came out to be $9.32 \%$, which is in agreement with the SDA contents achieved for both $2 \%$ as well as $6 \%$ cement stabilization. But, the validity of the model for SDA amended $4 \%$ cement stabilized soil still needs to be verified, for which a plot between the predicted SGR and evaluated SGR was done to check the relevance. Similar correlation between predicted and evaluated values have been done by earlier investigators to check the existence of a good correlation between prediction and evaluation and hence, the reliability of the models [38-39].

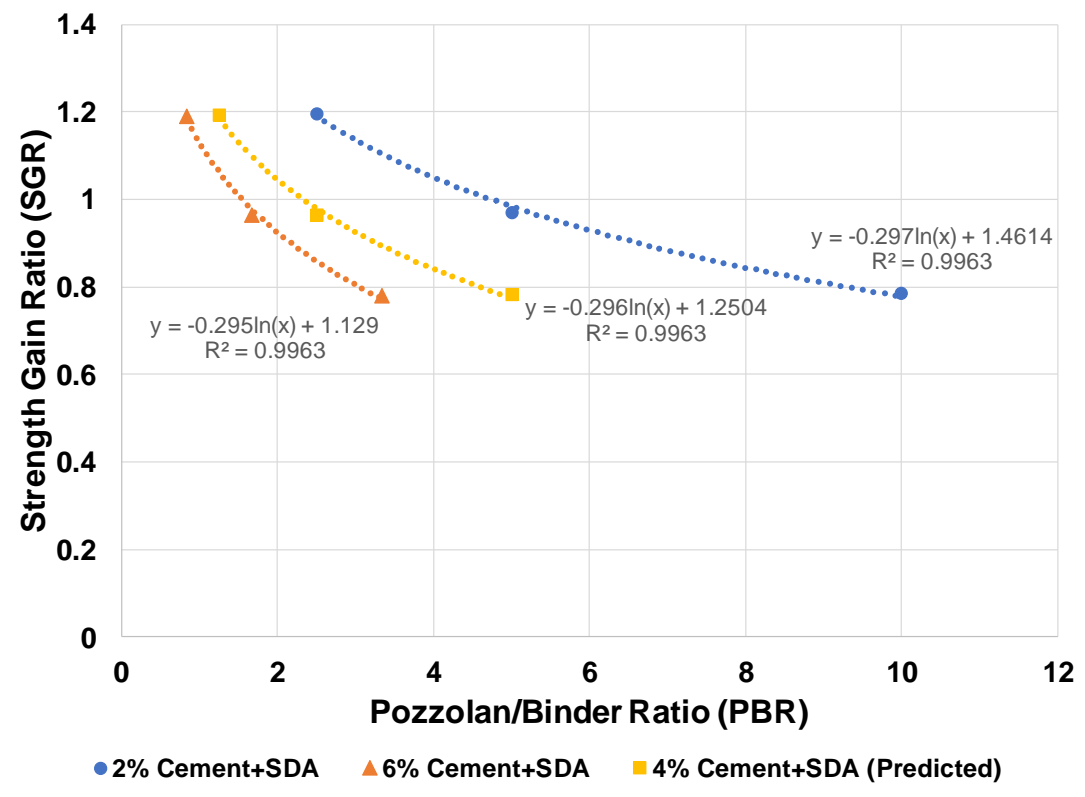

Fig. 4. Forecasted trend for $4 \%$ cement stabilized soil amended with SDA.

Figure 5 shows the relation between predicted and evaluated SGR values of $4 \%$ cement stabilized soil amended with SDA. It can be seen that the relation between actual SGR and predicted SGR is 0.9993 . The comparative assessment (based on $\mathrm{R}^{2}$ ) indicated that the developed model is in good agreement with the observed values [39]. For the purpose of comparison, the trendline for $R^{2}=1$ has also been shown. It is also clear that, the correlation is extremely good for SGR values of 1 and above. For SGR values of below 1, there is a marginal deviation of the trendline from perfect correlation. For SGR ratios of below 1, the forecast for $4 \%$ cement stabilized soil amended with SDA marginally underestimates the strength gain ratio. 


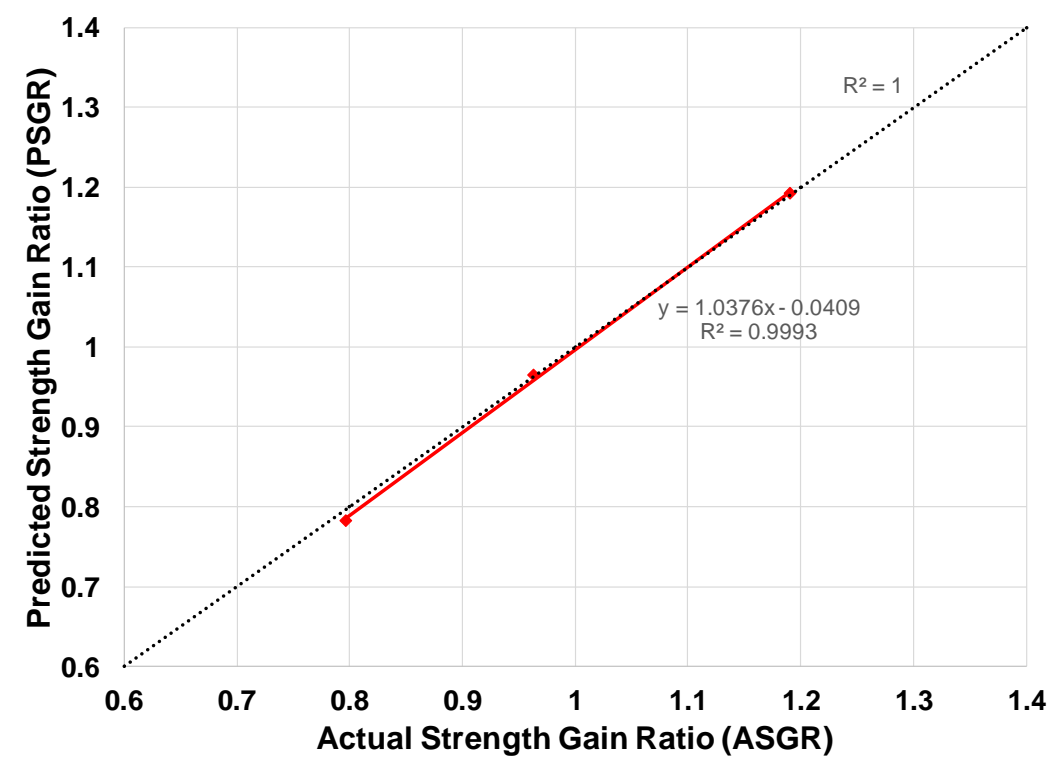

Fig. 5. Correlation between predicted and actual SGR for $4 \%$ cement-SDA stabilized soil.

\section{B. Percentage strength gain of SDA amended cement stabilized soil}

The extent of strength gain achieved by cement stabilized soil amended with SDA was analysed by a percentage strength gain analysis with additive quanta and curing period. Figures 6 and 7 show the percentage strength gains of $2 \%$ and $6 \%$ cement stabilized soil amended with SDA for different days of curing. It can be seen that for $2 \%$ cement stabilization, only $5 \%$ SDA is capable of producing positive strength gains across all curing periods whereas 20\% SDA results in strength loss across all curing periods. 10\% SDA was capable of gaining positive strength up to 14 days of curing beyond which there is a marginal loss in strength compared to pure cement stabilization. In the case of $6 \%$ cement stabilized soil, it can be seen that only $5 \%$ SDA was capable of producing positive strength gain whereas higher contents of SDA resulted in a strength loss across curing periods. An odd point to be noted is that even in the case of $5 \%$ SDA, at 14 days of curing, there was a marginal strength loss, which was anomalous compared to the general strength gain trend of the combination.

From Figures 6 and 7 , the first major observation that can be inferred is that SDA amendment in optimal dosage can amend both early as well delayed strength of the cement stabilized soil. The importance of early strength is well established with several researchers making it a part of their soil stabilization investigations [34, 40-46]. Development of early strength plays a crucial role in highway subgrade stabilization when there is a need for rapid opening of the road for traffic [47]. 


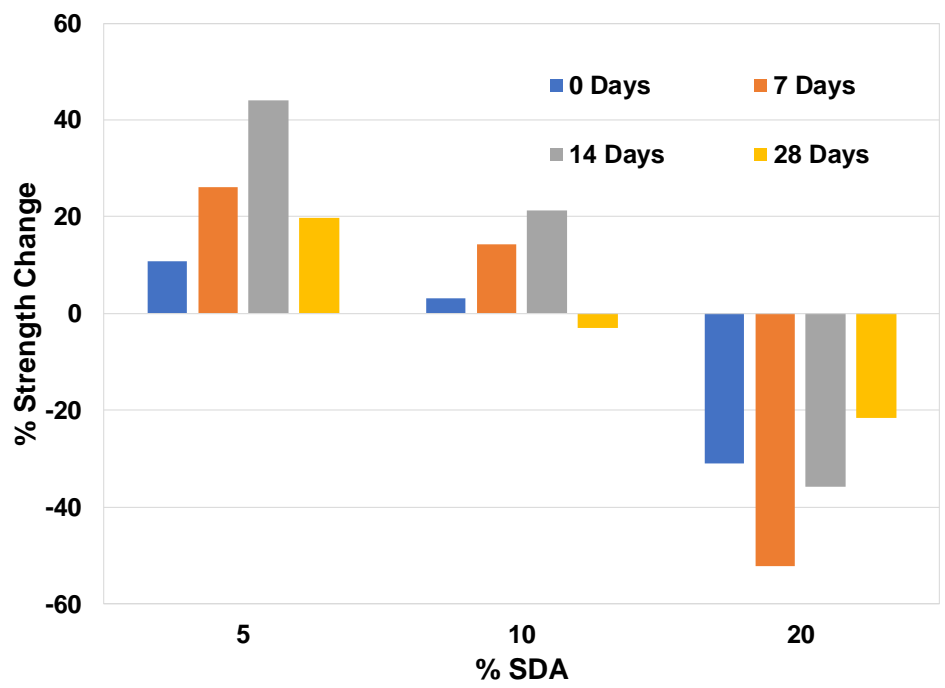

Fig. 6. Percentage strength gain of $2 \%$ cement stabilized soil with $\%$ SDA for different curing periods.

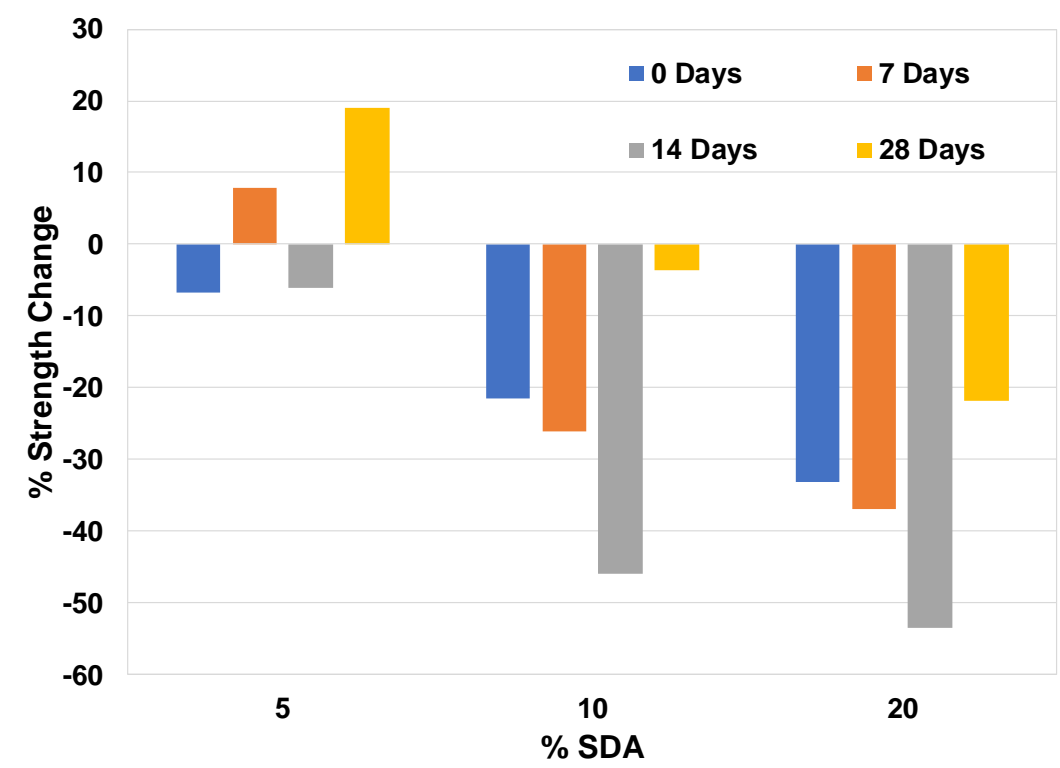

Fig. 7. Percentage strength gain of $6 \%$ cement stabilized soil with $\%$ SDA for different curing periods.

The second major observation is that at higher cement content, higher SDA content is detrimental to strength gain. This behaviour is similar to that found and reported for another type of agricultural biomass ash called bagasse ash when adopted in cement stabilization [32, 48-49]. Having said that the optimal dosage producing maximum strength gain is the same at 5\% SDA for both cement contents. This may have been due to the limitation of the test program which did not evaluate any SDA content lower than $5 \%$. The strength gains were also similar close to $19 \%$ for both the cases of cement stabilization with optimal SDA amendment. Thus, a more detailed test program is necessary to clearly conclude regarding the effectiveness of SDA at different cement contents.

The percentage analysis with subsequent curing period was performed for the cement stabilized soil in order to understand the extent of strength development in different stages of curing. The curing period of 28 days was divided into three 
stages based on the curing periods selected as first 7 days, next 7 days and last 14 days. The immediate strength of corresponding combination was used as the control strength for calculating the strength gain with curing and the percentage strength gained in the particular stage was reported. This percentage strength gain analysis with subsequent curing period is based on earlier works $[47,50]$. Figures 8 and 9 shows the percentage strength gain with subsequent curing periods.

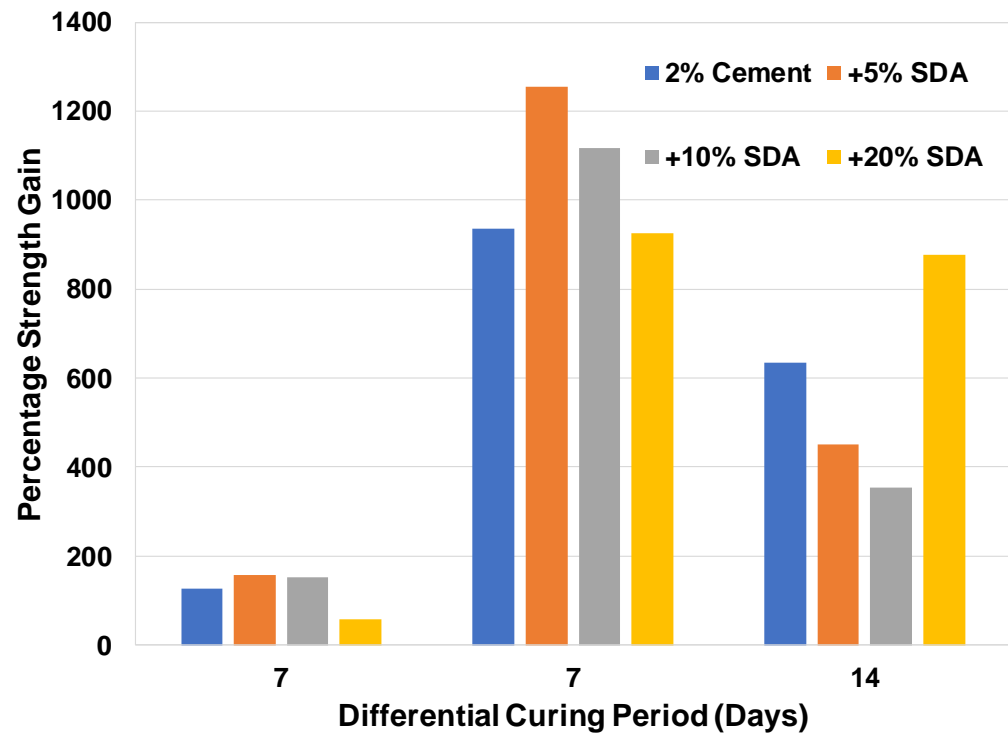

Fig. 8. Percentage strength gain of $2 \%$ cement stabilized soil with curing period.

It can be seen that in the case of $2 \%$ cement, the maximum gain in strength is achieved in stage 2, that is between 7 and 14 days of curing. The extent of gain is around $1000 \%$ for all the different combinations. In the third stage, that is between 14 and 28 days of curing, the there is significant gain in strength, however, not similar to that of second stage, but significantly greater than stage one of curing. Comparing the cement stabilized soil with amended soil specimens, it can be seen that the order of gain is similar for $2 \%$ cement stabilized soil and for the combination amended with $20 \%$ SDA at around $950 \%$. However, for the other two combinations, the strength gain was significantly higher, with a gain of more than $1100 \%$. This development of strength in cement stabilized soil was completely different from that of lime stabilized soil wherein most of the strength was developed within the first three days of curing [50]. This may be due to the clayey nature of the soil adopted in the investigation because of which the development of strength during cement stabilization is slower. It should be noted that cement stabilization of high plastic soils will result in marginal effectiveness [31]. In the case of $6 \%$ cement, the stages of strength development are different from that of $2 \%$ cement stabilization.

The maximum percentage strength gain is achieved in third stage of curing, that is between 14 and 28 days of curing. In contrast to $2 \%$ cement stabilized soil combinations, the strength gains in stage two was less than $900 \%$ for all combinations for $6 \%$ cement stabilized soil. The strength gains in stage three was extremely huge with amended specimens producing strength gain of more than $1350 \%$ whereas the control specimen had a strength gain of around $850 \%$. The increase in strength in stage three may have been due to the availability of more 
cement content due to which the pozzolanic reaction was able to proceed for a longer duration, leading to a higher strength gain in stage three. Increase in binder content can result in increase in the strength of the stabilized soil in latter stages of curing as reported in an earlier study for lime stabilized soil [47].

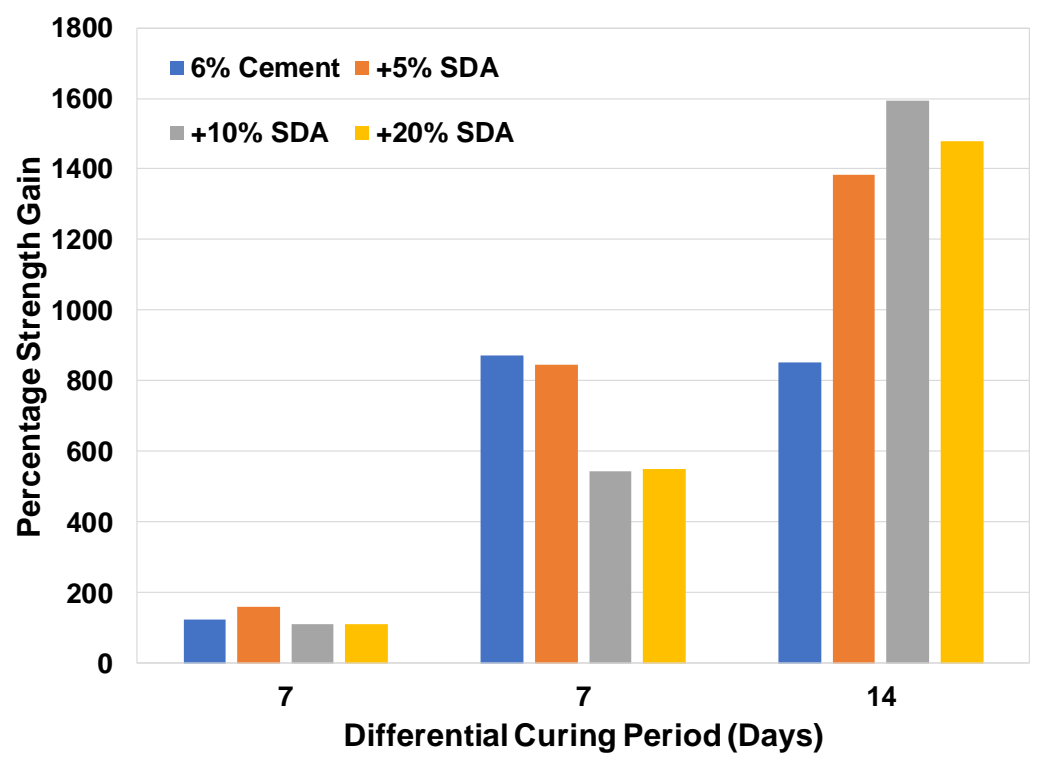

Fig. 9. Percentage strength gain of $6 \%$ cement stabilized soil with curing period.

\section{Benefits of SDA amendment of cement stabilization of subgrade}

In order to evaluate the beneficial effect of introducing SDA into cement stabilization of a pavement subgrade, a flexible pavement on top of the cement stabilized subgrade as well as the optimally amended stabilized subgrade was designed. The recommended method for design of flexible pavement by the Indian Roads Congress (IRC) is based on the California Bearing Ratio (CBR) method. Since, the present investigation focussed on the UCS of the stabilized specimens for evaluating its strength benefits due to its simplicity and small requirement of materials, it was not possible to directly adopt the strength obtained from the UCS tests for design of a flexible pavement based on the IRC recommended method. So, it became imperative to translate the UCS to CBR for design of a flexible pavement for the aforementioned purpose. A sift through literature revealed the relationship between the UCS and CBR for cement stabilized sand mixtures given by O'Flaherty et al. [51] for the very purpose of predicting the CBR of stabilized soil from the more easily and quickly obtained UCS and the relation given by Usluogullari and Vipulanandan [52] for predicting the CBR of cement stabilized sands based on cement content and curing period.

The predicted CBR values based on its relationship with UCS given by O'Flaherty et al. [51] were over estimated. Hence, the CBR values were predicted based on the relationships given by Usluogullari and Vipulanandan [52] and are tabulated in Table 2 for immediate UCS strength at 2 hours of curing. The choice of 2 hours curing was due to the fact that UCS values corresponding to higher curing periods resulted in high values of CBR. The values of CBR were too high to show clear differences in pavement thickness. The relationships given in equations (1) and (2) were adopted for prediction of CBR values and rounded off to the nearest whole number. 


$$
\begin{aligned}
& \operatorname{UCS}(\mathrm{kPa})=\mathrm{T}_{c} /\left(0.0197 \times \mathrm{C}^{-1.41}+0.0069 \times \mathrm{C}^{-1.46} \times \mathrm{T}_{\mathrm{c}}\right) \\
& \operatorname{CBR}(\%)=\mathrm{T}_{c} /\left(0.14 \times \mathrm{C}^{-1.55}+0.03 \times \mathrm{C}^{-1.44} \times \mathrm{T}_{\mathrm{c}}\right)
\end{aligned}
$$

Where, $\mathrm{T}_{\mathrm{C}}=$ Curing period in days, and $\mathrm{C}=$ Cement content in $\%$.

Table 2. Predicted CBR values of cement stabilized soil.

\begin{tabular}{|c|c|c|}
\hline Cement (\%) & SDA (\%) & Predicted CBR (\%) \\
\hline 2 & 0 & 51 \\
\hline 2 & 5 & 56 \\
\hline 6 & 0 & 89 \\
\hline 6 & 5 & 83 \\
\hline
\end{tabular}

Based on the predicted CBR values from the UCS, the thickness of the pavement was calculated using the relationship chart given by Alam Singh [53] shown in Figure 10. Vijay [54], in an earlier work, had adopted the relationship chart for calculation of thicknesses of flexible pavements, supported on top of crumb rubber modified clay for different vehicle densities, based on their CBR values. From the chart it can be seen that for lighter vehicle traffic, there is no big difference in the pavement thickness for cement stabilized and amended samples. However, for heavier traffic, that is for categories $D, E, F$ and $G$, there is a noticeable difference in pavement thickness.

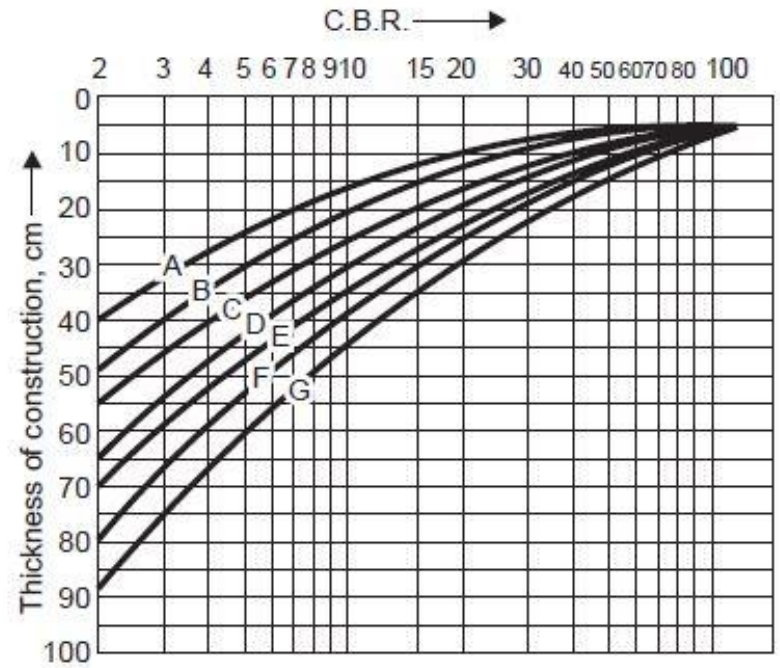

\begin{tabular}{|c|c|}
\hline Curve & No. of vehicles day $(>3 t)$ \\
\hline A & $0-15$ \\
\hline B & $15-45$ \\
\hline C & $45-150$ \\
\hline D & $150-450$ \\
\hline E & $450-1500$ \\
\hline F & $1500-4500$ \\
\hline G & Over 4500 \\
\hline
\end{tabular}

Fig. 10. Design charts for flexible pavement - CBR method (After Alam Singh [53]).

Figure 11 shows the comparison of pavement thickness for different vehicle density categories for $2 \%$ cement stabilized subgrade and 5\% SDA amended subgrade. For category $\mathrm{G}$, the pavement thickness reduced by $12 \mathrm{~mm}$ from $145 \mathrm{~mm}$ to $133 \mathrm{~mm}$ due to the addition of $5 \%$ SDA amendment whereas for other cases of $D, E$ and $F$, the reduction in thicknesses were $7 \mathrm{~mm}, 9 \mathrm{~mm}$ and $11 \mathrm{~mm}$ respectively from original thicknesses of $92 \mathrm{~mm}, 111 \mathrm{~mm}$ and $122 \mathrm{~mm}$. This translates to a reduction in thickness in the range of $7.6 \%$ to $8.3 \%$ which is a noticeable gain. The $6 \%$ cement stabilized subgrade will give a much thinner pavement. Since the SDA amendment at 2 hours curing yielded a lower CBR, the thickness comparison was not analysed for $6 \%$ cement stabilization. As 
mentioned earlier, predicted CBR values are too high at higher curing periods to bring out the gains in pavement thickness for $6 \%$ cement stabilization.

Actual CBR values can give a realistic estimate of savings in pavement thickness. Moreover, the stabilized soil can also be beneficially used as a part of the base course or sub base course of the flexible pavement. Indian Roads Congress (IRC) code [55] recommends strength criteria of 0.7 to $1.5 \mathrm{MPa}$ at 7 days of curing for stabilized soil sub-bases to be used in design of flexible pavements. In the present case, the 5\% SDA amended $2 \%$ cement stabilized subgrade has a strength of $0.93 \mathrm{MPa}$ and hence, can also be adopted in the design of sub-base of pavements. However, the SDA amended cement stabilized soil, even at higher cement content, could not develop the minimum strength of $4.5 \mathrm{MPa}$ at 7 days of curing to be used as stabilized base in pavement construction [55]. Thus, the present SDA amended cement stabilized soil can also be used as stabilized sub base layer in pavement construction, apart from forming the subgrade.

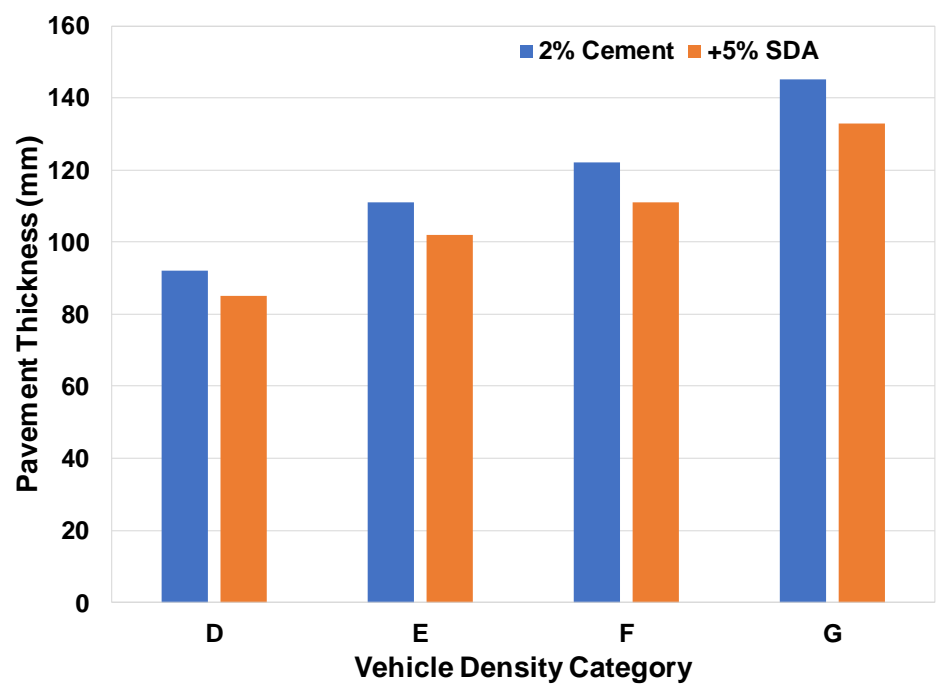

Fig. 11. Comparison of pavement thickness with and without SDA amendment.

\section{Limitations of the study}

The results and hence, conclusions of the study, however, need to be taken along with the limitations of the study. A major limitation of the study is the use of a predictive equation for generating CBR values for use in the pavement thickness calculation. The use of predictive equations for basing an analysis is always debatable. However, in the present study, the use of the predictive equations to generate CBR was to overcome the inherent shortcoming of the experimental program that adopted only UCS testing due to its simplicity while pavement design is predominantly based on CBR. The pavement thickness calculation based on the predicted CBR was to merely indicate the benefits that SDA amendment can provide in terms of reduction in thickness. It should also be noted that the predicted CBR values were based on unsoaked UCS values whereas only soaked CBR values are adopted for design of pavement. Having said that, IRC code [55] mentions that for areas having annual rainfall of less than $1000 \mathrm{~mm}$, the soaked CBR is too severe a condition for a well-protected subgrade with a thick bituminous layer leading to under estimation of soil strength. Hence, the results of this study can only be applied to arid and semi-arid regions with low annual rainfall. 


\section{Conclusions}

The experimental investigation tried to evaluate the potential benefits of amending cement stabilization of an expansive soil with SDA, a waste generated due to burning of saw mill waste. The program involved amending cement stabilized soil with SDA and evaluating its UCS, which was used to predict its CBR for analysing savings in pavement thickness. Based on the results of the investigation and the subsequent analysis of pavement thicknesses, the following points can be concluded.

(i) SDA amendment of cement stabilization resulted in an increase in both early as well as delayed strength. The SDA amendment results in a minimum increase of $8 \%$ in early strength at 7 days of curing and $19 \%$ increase in delayed strength at 28 days of curing.

(ii) SDA amendment to the tune of $5 \%$ was found to be optimal for both the cement contents adopted in the investigation. Higher SDA contents results in a drop in the strength of the stabilized soil. Based on the relationships developed between SDA to cement content ratio and the strength gain ratio, it was found that for cement contents of $5 \%$ and below (soil cement), the maximum addition of SDA should be restricted to $9 \%$ for no loss in strength compared to control specimens. Higher SDA contents are detrimental to strength gain, even when the cement contents are higher.

(iii) The strength development patterns show a marked difference from that of lime stabilization wherein the maximum gain in strength within a particular period varies with cement content. At lower cement content, the maximum strength gain was within the second stage of seven days while in the case of the higher cement content, the maximum strength gain was in the last stage of 14 days.

(iv) Based on the predicted CBR values of the stabilized specimens from the UCS values, it can be stated that SDA amendment of cement stabilization of subgrade can results in noticeable savings in pavement thickness in the range of 7.6 to $8.3 \%$ for moderate to heavy traffic category in arid regions with low annual rainfall. Moreover, SDA amended cement stabilized soil can also develop enough strength to be used as sub-base material in the actual construction of the pavement but fails to meet the requirements for use as stabilized base courses.

The true benefits of SDA amendment can be clearly obtained by carrying out unsoaked and soaked CBR tests on the stabilized specimens, which can be carried out in future investigations.

\section{Acknowledgements}

The author is thankful to Mr. M. Sasi Kumar, Lab instructor and undergraduate students of Civil Engineering for helping out with the laboratory testing of the specimens.

\section{References}

[1] A. Sabat, and S. Pati, "A Review of Literature on Stabilization of Expansive Soil Using Solid Wastes," Electron. J. Geotech. Eng., vol. 19, pp. 6251-6267, 2014.

[2] J. James, and P. K. Pandian, "Soil Stabilization as an Avenue for Reuse of Solid Wastes: A Review," Acta Tech. Napocensis Civ. Eng. Arch., vol. 58 (1), pp. 50-76, 2015.

[3] H. Karim, M. Al-Recaby, and M. Nsaif, "Stabilization of soft clayey soils with sawdust ashes," MATEC Web Conf., 
vol. 162 (01006), pp. 1-7, 2018. DOI: https://doi.org/10.1051/matecconf/201816201006.

[4] W. A. Butt, K. Gupta, and J. N. Jha, "Strength behavior of clayey soil stabilized with saw dust ash," Geo-Engineering, vol. 7 (1), p. 18, Dec. 2016. DOI: https://doi.org/10.1186/s40703-016-0032-9.

[5] T. H. T. Ogunribido, "Geotechnical Properties of Saw Dust Ash Stabilized Southwestern Nigeria Lateritic Soils," Environ. Res. Eng. Manag., vol. 2 (60), pp. 29-33, 2012. DOI: https://doi.org/10.5755/j01.erem.60.2.986.

[6] G. R. Otoko, and B. K. Honest, "Stabilization of Nigerian Deltaic Laterites with Sawdust Ash," Int. J. Sci. Res. Manag., vol. 2 (8), pp. 1287-1292, 2014.

[7] A. O. Ilori, "Investigation of Geotechnical Properties of a Lateritic Soil with Sawdust Ash," IOSR J. Mech. Civ. Eng., vol. 12 (1), pp. 11-14, 2015.

[8] S. Khan, and H. Khan, "Improvement of mechanical properties by waste sawdust ash addition into soil," Electron. J. Geotech. Eng., vol. 20 (7), pp. 1901-1914, 2015.

[9] B. D. Nath, G. Sarkar, S. Siddiqua, and R. Islam, "Geotechnical Properties of Wood Ash-Based Composite FineGrained Soil," Hindawi, vol. 2018, p. 7, 2018. DOI: https://doi.org/10.1155/2018/9456019.

[10] E. Kufre, C. Chijioke, E. Edidiong, and C. Imoh, "Influence of Sawdust Disposal on the Geotechnical Properties of Soil," Electron. J. Geotech. Eng., vol. 22 (12), pp. 4769-4780, 2017.

[11] A. Venkatesh, and G. S. Reddy, "Effect Of Waste Saw Dust Ash On Compaction And Permeability Properties Of Black Cotton Soil," Int. J. Civ. Eng. Res., vol. 7 (1), pp. 27-32, 2016.

[12] E. A. Okunade, "The Effect of Wood Ash and Sawdust Admixtures on the Engineering Properties of Burnt Laterite Clay Brick," J of Applied Science, vol. 8 (6), pp. 1042-1048, Jan. 2008. DOI: https://doi.org/10.3923/jas.2008.1042.1048.

[13] J. E. Edeh, I. O. Agbede, and A. Tyoyila, "Evaluation of Sawdust Ash - Stabilized Lateritic Soil as Highway Pavement Material," J. Mater. Civ. Eng., vol. 26 (2), pp. 367-373, Feb. 2014. DOI: https://doi.org/10.1061/(ASCE)MT.1943-5533.0000795.

[14] K. J. Osinubi, J. E. Edeh, and W. O. Onoja, "Sawdust Ash Stabilization of Reclaimed Asphalt Pavement," J. ASTM Int., vol. 9 (2), pp. 1-10, 2011.

[15] A. A. Raheem, B. S. Olasunkanmi, and C. S. Folorunso, "Saw Dust Ash as Partial Replacement for Cement in Concrete," Organ. Technol. Manag. Constr. An Int. J., vol. 4 (2), pp. 474-480, 2012.

[16] D. N. Little, "Handbook for Stabilization of Pavement Subgrades and Base Courses with Lime," Austin, Texas, 1995.

[17] J. James and P. K. Pandian, "Industrial Wastes as Auxiliary Additives to Cement / Lime Stabilization of Soils," Adv. Civ. Eng., vol. 2016, Article ID 1267391, pp. 1-17, 2016.

[18] K. D. Rao, M. Anusha, P. R. T. Pranav, and G. Venkatesh, "A Laboratory Study on the Stabilization of Marine Clay Using Saw Dust and Lime," ljesat] Int. J. Eng. Sci. Adv. Technol., vol. 2 (4), pp. 851-862, 2012.

[19] E. S. Nnochiri, H. O. Emeka, and M. Tanimola, "Geotechnical Characteristics of Lateritic Soil Stabilized With Sawdust Ash-Lime Mixtures," Stavební Obz. - Civ. Eng. J., vol. 26 (1), pp. 66-76, 2017.

[20] Z. Z. Shawl, V. Praksh, and V. Kumar, "Use of Lime and Saw Dust Ash in Soil," Int. J. Innov. Res. Sci. Eng. Technol., vol. 6 (2), pp. 1682-1689, 2017

[21] S. T. Tyagher, J. T. Utsev, and T. Adagba, "Suitability of Saw Dust Ash-Lime Mixture for Production of Sandcrete Hollow Blocks," Niger. J. Technol., vol. 30 (1), pp. 1-6, 2011.

[22] A. J. Gana, and J. B. Tabat, "Stabilization of Clay Soil with Cement and Sawdust," CARD Int. J. Eng. Emerg. Sci. Discov., vol. 2 (3), pp. 1-27, 2017.

[23] H. I. Owamah, E. Atikpo, O. E. Oluwatuyi, and A. M. Oluwatomisin, "Geotechnical Properties of Clayey Soil Stabilized with Cement-Sawdust Ash for Highway Construction," J. Appl. Sci. Environ. Manag., vol. 21, no. 7, pp. 1378-1381, 2017.

[24] BIS, IS 2720 Methods of Test for Soils:Part 5 Determination of Liquid and Plastic Limit. India, 1985, pp. 1-16.

[25] BIS, IS 2720 Methods of Test for Soils:Part 6 Determination of Shrinkage Factors. India, 1972, pp. 1-12.

[26] BIS, IS 2720 Methods of Test for Soils Part 3:Determination of Specific Gravity/Section 1 Fine Grained Soils. India, 1980, pp. 1-8.

[27] BIS, IS 2720 Methods of Test for Soils:Part 7 Determination of Water Content-Dry Density Relation Using Light Compaction. India, 1980, pp. 1-9.

[28] BIS, IS 2720 Methods of Test for Soils:Part 10 - Determination of Unconfined Compressive Strength. India, 1991, pp. 1-4.

[29] BIS, IS 2720 Methods of Test for Soils:Part 40 Determination of Free Swell Index of Soils. India, 1977, pp. 1-5.

[30] BIS, IS 1498 Classification and Identification of Soils for General Engineering Purposes. India, 1970, pp. 4-24.

[31] Transport Research Laboratory, "Literature Review:Stabilised Sub-Bases for Heavily Trafficked Roads," Project Report Origin PR/INT/202/00, 2003, 38 p.

[32] J. James, P. K. Pandian, K. Deepika, J. M. Venkatesh, V. Manikandan, and P. Manikumaran, "Cement Stabilized Soil Blocks Admixed with Sugarcane Bagasse Ash," Journal of Engineering, vol. 2016, pp. 1-9, 2016. DOI: https://doi.org/10.1155/2016/7940239.

[33] M. Kharun, and A. P. Svintsov, "Soil-cement ratio and curing conditions as the factors of soil-concrete strength," KEM, vol. 730, pp. 358-363, Feb. 2017. DOI: https://doi.org/10.4028/www.scientific.net/KEM.730.358.

[34] J. James, and P. K. Pandian, "A Study on the Early UCC Strength of Stabilized Soil Admixed with Industrial Waste Materials," Int. J. Earth Sci. Eng., vol. 7 (3), pp. 1055-1063, 2014.

[35] S. Saride, A. J. Puppala, and S. R. Chikyala, "Swell-shrink and strength behaviors of lime and cement stabilized expansive organic clays," Applied Clay Science, vol. 85, pp. 39-45, Nov. 2013. DOI: https://doi.org/10.1016/j.clay.2013.09.008.

[36] E. A. Basha, R. Hashim, H. B. Mahmud, and A. S. Muntohar, "Stabilization of residual soil with rice husk ash and cement," Construction and Building Materials, vol. 19 (6), pp. 448-453, Jul. 2005. DOI: https://doi.org/10.1016/i.conbuildmat.2004.08.001.

[37] S. Chowdhury, M. Mishra, and O. Suganya, "The incorporation of wood waste ash as a partial cement replacement material for making structural grade concrete: An overview," Ain Shams Engeneering Journal, vol. 6 (2), pp. 429437, Jun. 2015. DOI: https://doi.org/10.1016/i.asej.2014.11.005.

[38] F. Meulenkamp, and M. A. Grima, "Application of neural networks for the prediction of the UCS from Equotip hardness," International Journal of Rock Mechanics and Mining Sciences, vol. 36 (1), pp. 29-39, Jan. 1999. DOI: https://doi.org/10.1016/S0148-9062(98)00173-9.

[39] A. K. Sabat, "Statistical Models for Prediction of Swelling Pressure of a Stabilized Expansive Soil," Electron. J. Geotech. Eng., vol. 17, pp. 837-846, 2012.

Revista Facultad de Ingeniería (Rev. Fac. Ing.) Vol. 28 (50), pp. 44-61. Enero-Marzo, 2019. Tunja-Boyacá, Colombia. L-ISSN: 0121-1129, e-ISSN: 2357-5328, DOI: 
[40] M. Tao, and Z. Zhang, "Enhanced Performance of Stabilized By-Product Gypsum," J. Mater. Civ. Eng., vol. 17 (6), pp. 617-623, Dec. 2005. DOI: https://doi.org/10.1061/(ASCE)0899-1561(2005)17:6(617).

[41] Y. Xizhong, L. Shudong, and C. Wei, "Silt Subgrade Modification and Stabilization with Ground Granulated Blast Furnace Slag and Carbide Lime in Areas with a Recurring High Groundwater," in Proceedings of International Conference on Mechanic Automation and Control Engineering, 2010, pp. 2063-2067.

[42] P. V. Sivapullaiah, and A. K. Jha, "Gypsum Induced Strength Behaviour of Fly Ash-Lime Stabilized Expansive Soil," Geotech. Geol. Eng., vol. 32 (5), pp. 1261-1273, Oct. 2014. DOI: https://doi.org/10.1007/s10706-014-9799-7.

[43] J. James, and P. K. Pandian, "Role of Phosphogypsum and Ceramic Dust in Amending the Early Strength Development of a Lime Stabilized Expansive Soil," Int. J. Sustain. Constr. Eng. Technol., vol. 7 (2), pp. 38-49, 2016.

[44] S. M. Al-zaidyeen, and A. N. S. Al-qadi, "Effect of Phosphogypsum As a Waste Material in Soil Stabilization of Pavement Layers," Jordan J. Civ. Eng., vol. 9 (1), pp. 1-7, 2015.

[45] J. James, and P. K. Pandian, "Development of Early Strength of Lime Stabilized Expansive Soil: Effect of Red Mud and Egg Shell Ash," Acta Tech. Corviniensis - Bull. Eng., vol. 9 (1), pp. 93-100, 2016.

[46] Z. Wang, X. Si-fa, and W. Guo-cai, "Study of Early Strength and Shrinkage Properties of Cement or Lime Solidified Soil," Energy Procedia, vol. 16, pp. 302-306, Jan. 2012. DOI: https://doi.org/10.1016/i.egypro.2012.01.050.

[47] J. James, and P. Kasinatha Pandian, "Bagasse Ash as an Auxiliary Additive to Lime Stabilization of an Expansive Soil: Strength and Microstructural Investigation," Adv. Civ. Eng., vol. 2018, 2018.

[48] S. A. Lima, H. Varum, A. Sales, and V. F. Neto, "Analysis of the mechanical properties of compressed earth block masonry using the sugarcane bagasse ash," Construction and Building Materials, vol. 35, pp. 829-837, Oct. 2012. DOI: https://doi.org/10.1016/j.conbuildmat.2012.04.127.

[49] V. Greepala, and R. Parichartpreecha, "Effects of Using Flyash, Rice Husk Ash and Bagasse Ash as Replacement Materials on the Compressive Strength and Water Absorption of Lateritic Soil-Cement Interlocking Blocks," in Proceedings of 9th Australasian Masonry Conference, 2011, pp. 583-603.

[50] S. Bhuvaneshwari, R. G. Robinson, and S. R. Gandhi, "Behaviour of Lime Treated Cured Expansive Soil Composites," Indian Geotech. J., vol. 44 (3), pp. 278-293, Sep. 2014. DOI: https://doi.org/10.1007/s40098-0130081-3.

[51] C. A. O'Flaherty, H. T. David, and D. T. Davidson, "Relationship Between the California Bearing Ratio and the Unconfined Compressive Strength of Sand-Cement Mixtures," Proc. lowa Acad. Sci., vol. 68 (1), pp. 341-356, 1961.

[52] O. F. Usluogullari, and C. Vipulanandan, "Stress-Strain Behavior and California Bearing Ratio of Artificially Cemented Sand," J. Test. Eval., vol. 39 (4), p. 103165, 2011. DOI: https://doi.org/10.1520/JTE103165.

[53] A. Singh, Soil Engineering in Theory and Practice. Bombay, India: Asia Publishing House, 1967.

[54] S. Vijay, "Stress-strain and penetration characteristics of clay modified with crumb rubber," Revista Facultad de Ingeniería, vol. 28 (49), pp. 65-75, 2018. DOI: https://doi.org/10.19053/01211129.v28.n49.2018.8745.

[55] Indian Roads Congress, IRC 37: Guidelines for the design of flexible pavements, no. July. New Delhi, India, 2012, pp. 1-104. 